\title{
Honey and propolis production, hygiene and defense behaviors of two generations of Africanized honey bees
}

\author{
Regina Conceição Garcia ${ }^{1 *}$, Newton Tavares Escocard de Oliveira ${ }^{1}$, Simone Cristina Camargo ${ }^{1}$, Bruno Garcia Pires ${ }^{2}$, Carlos \\ Antonio Lopes de Oliveira ${ }^{3}$, Rodrigo de Almeida Teixeira1,\$, Maricéia Ana Pickler ${ }^{1}$
}

\author{
${ }^{1}$ UNIOESTE/Centro de Ciências Agrárias, C.P. 91 - 85960- \\ 000 - Marechal Cândido Rondon, PR - Brasil. \\ 2UNIOESTE/Centro de Ciências Biológicas e da Saúde, C.P. \\ 701 - 85819-110 - Cascavel, PR - Brasil. \\ 3UEM - Depto. de Zootecnia, Av. Colombo, 5790 - 87020 \\ 900 - Maringá, PR - Brasil. \\ *Corresponding author <garcia.regina8@gmail.com>
}

Edited by: Richard V. Glatz

\begin{abstract}
Phenotypic characters of honeybees, relevant to beekeepers, can be evaluated by studying correlations between them, and the correlated characteristics can be evaluated in the short term to assist in monitoring of annual genetic progress. This work therefore aims to evaluate the production of honey and propolis, the hygiene and defensive behaviours of two generations of Africanized Apis mellifera (Hymenoptera, Apidae), to estimate the correlations between them and their heritability. We used 30 Langstroth beehives in apiaries in Marechal Cândido Rondon, Paraná State, Brazil. We used a method of drilling pupae to evaluate hygiene behaviour and the velveteen ball method to test defensive behaviour. We selected ten colonies which had the best honey and propolis production, and which produced F1 queens that were then transferred to beehives at an experimental farm, in order to observe honey and propolis production, hygiene and defence behaviours of their female offspring. The estimated differences for each characteristic between the generations, the correlations between them within each generation and their heritability suggest that selection of colonies based on propolis production was more efficient at maintaining this high production than was selection based on honey production according to the performance of the colonies for this characteristic. The selected behavioural characteristics can be used to enhance performance, but not for improving yield characteristics evaluated. Keywords: Apis mellifera, animal production, ethology, selection
\end{abstract}

Received April 28, 2011
Accepted November 13, 2012

\section{Introduction}

The honeybee Apis mellifera L. (Hymenoptera, Apidae) is clustered into subspecies or geographical races, based on possession of similar characteristics and region of origin, also called as "races of tropical or temperate evolution" (Rinderer, 1986; Hepburn and Radloff, 1998; Winston, 1987). Although there are morphometric differences among tropical African races of honeybee, they share many common features that are mainly adaptations to their common tropical environment, called "tropical honeybee characteristics". These include seek shelter in smaller cavities, to stock less food for the winter period and invest more in offspring than in food, greater capacity for swarming and defence, and also are found, in tropical Apis races (Fletcher, 1978; Rinderer, 1986; Garcia and Nogueira-Couto, 2003; Winston, 1987).

Swarms from 26 colonies of the African honeybee A. m. scutellata L. escaped in Brazil in 1957, making crossing and backcrossing with previously introduced European honeybee races, initiating a hybridization process called "africanization" of the honeybee (Kerr, 1967; Sheppard et al., 1991a,b; Clarke et al., 2002). In less than 50 years, Africanized honeybees had spread throughout South, Central and North America (De Jong, 1996; Kaplan, 2007), replacing of the latter by the former in the Neotropical regions (Lobo and Krieger, 1992; Gusmán-Novoa et al., 2005). This rapid expansion has

sPresent Address: UFPR - Depto. de Zootecnia, R. dos Funcionários, 1540 80035-050 - Curitiba, PR - Brasil. been attributed to the rapid introgression and increase in the prevalence of mitochondria of African origin of the African genotype in areas previously dominated by European genotypes (Smith et al., 1989), adaptation and reproductive efficiency of the Africanized bees, which inherited adaptive characteristics of their African ancestors (Fletcher, 1978; Rinderer, 1986; Rinderer et al., 1993; Winston, 1987).

Honey production in Brazil grew by $97.3 \%$ and propolis production by $232.7 \%$ in 2001/02 (SEBRAE, 2006), due to export demand. In 2009, the state of Paraná was the second largest producer of honey, and western Paraná accounted for approximately $20 \%$ of this production (IBGE, 2009), mainly from small producers, who generally do not exchange or select queens and do not produce propolis commercially. The genetic improvement of $A$. mellifera, mainly of European races, for honey production has been practised for decades (Rinderer, 1986); however, little has been achieved in genetic improvement for propolis production.

This work therefore aims to evaluate honey and propolis production, both in the context of its high commercial potential in the region, as well as in terms of the hygiene and defence behaviours of two generations of Africanized $A$. mellifera, and estimates their correlations and heritability.

\section{Materials and Methods}

Africanized $A$. mellifera L. colonies were utilized in this study and comprised two stages. The first stage 
was undertaken from June 2007 until January 2008, at five properties in Novo Horizonte, Boa Vista and Margarida, districts of Marechal Cândido Rondon (24⒊'40" S; $54^{\circ} 04^{\prime} 00^{\prime \prime} \mathrm{W} ; 400 \mathrm{~m}$ altitude), Parana state, Brazil, with colonies managed for honey production, but non-selected. The second stage was undertaken from January 2008 until January 2009 in Marechal Cândido Rondon, using the hives established on the site, and queens that were later replaced, as described later.

The region's climate is subtropical, with rain well-distributed throughout the year and hot summer seasons. The mean temperature of the coldest trimester varies between $17^{\circ} \mathrm{C}$ and $18{ }^{\circ} \mathrm{C}$, of the hottest semester varies between $28{ }^{\circ} \mathrm{C}$ and $29^{\circ} \mathrm{C}$, and the annual mean is temperate, between $22{ }^{\circ} \mathrm{C}$ and $23{ }^{\circ} \mathrm{C}$. The mean precipitation varies between 1,600 and $1,800 \mathrm{~mm}$, with its most rainy trimester having $400 \mathrm{~mm}$ to $500 \mathrm{~mm}$ of rain (IAPAR, 2008).

Initially, we evaluated six colonies per apiary, a total of 30 colonies, according to their propolis and honey production, and their hygiene and defence behaviours. We selected the best honey producer and the best propolis producer (selection criteria) from each apiary, and we then produced queen bees $\left(\mathrm{F}_{1}\right)$ from these colonies, so that the worker bees descending from these ten queens could be evaluated in the same environment, that is, the apiary at the experimental farm.

Honeycombs hosting one- to three-day-old larvae from the ten hives were selected and moved to the laboratory to produce queens in the apiary at the experimental farm. We transferred larvae, in a method adapted from Doolittle (1899), from their alveolus to plastic recipients containing one drop of royal jelly, in which they were placed. On the $10^{\text {th }}$ day after transfer, all the queen cells with pupa were placed in Miller cages with a small amount of extra fine sugar with honey, and then waited for the queens to emerge in this same hive. Ten receptor colonies for these daughter queens $\left(\mathrm{F}_{1}\right)$ were used, taking 50 days to evaluate the productive and behavioural characteristics of the descending worker bees.

To evaluate propolis production, Apis Flora-type collectors were used, as described by Manrique and Soares (2002a), introduced both between and above the nests, and carried out weekly collections from June to August. The parental as well as descendant colonies were fed weekly with a protein supplement, based on soy scraps, wheat and corn, and containing sugar and water, from June to August in both 2007 and 2008.

To evaluate honey production in parental and F1 generations, honeycombs were chosen with a minimum of $2 / 3$ capped combs as this reduces the level of subsequent fermentation because capped honey is ideal for storage and contains around 17-18\% moisture, while uncapped honey (green honey) still has too much moisture for storage (Nogueira-Couto and Couto, 2006). These honeycombs would all be taken to the Honey Beneficiation Unit (UBM), decapped and the honey extracted and weighed.
The defensivity test was conducted according to the method adapted by Brandenburgo (1993), in which a black velveteen ball of two centimetres in diameter was waved near the hive entrance for $60 \mathrm{~s}$. The time intervals until the first sting and the formation of the cluster as a heat-ball of bees on the ball were measured, as well as the number of sings left in the ball after $60 \mathrm{~s}$. The test was carried out at $3 \mathrm{PM}$ and $5 \mathrm{PM}$, only once in the parental generation (October 2007) and in the $\mathrm{F}_{1}$ generation (May 2008).

The hygiene behavioural test was carried out according to the methods described by Gramacho and Gonçalves (2009a), by perforating 100 pupae (area of $10 \times 10$ alveoli) from combs from the tested colonies, using an entomological pin "size no. two". After perforation, the comb was replaced in the hive where it remained for 24 hours for decapping by worker bees and removal of the dead or defective offspring. After this period, the number of decapped cells was calculated, and hives that had removed 80 $\%$ of dead offspring after $24 \mathrm{~h}$ were considered to be hygienic and those that had removed less than 80 $\%$ were considered unhygienic (Gramacho and Gonçalves, 2009a).

In the second stage of the research in Marechal Cândido Rondon, we undertook an initial mapping of the combs in the hives, according to the method adapted by Al-Tikrity et al. (1971) for homogenizing the distribution of the offspring (eggs, larvae and pupae) and food (honey and pollen) quantities, before the queens selected at the first stage were introduced. Thus, both the external and internal environments of the hives for the descendent generation (F1) were homogenous.

Our hypothesis was that there is no difference in the production of honey and propolis between the parental and descendant generations, regardless of the selection criteria adopted. With respect to correlations, the hypothesis was that there is no correlation between the observed phenotypic characteristics. The aim of experiments is usually to determine the differences and reject the null hypothesis (Snedecor and Cochran, 1989).

For the statistical analyses, we used System Statistics and Genetics Analysis software (R. Development Core Team. 2011). Pearson's correlation was used between the dependent variables, and a $\mathrm{T}$ test was used to compare means. The estimation of components of variance and degree of heritability of the phenotypes was carried out using mother-daughter regression analysis, based on a Bayesian approach, through the Multiple Trait Gibbs Sampling in Animal Models software developed by Van Tassel and Van Vleck (1995); this software undertakes Bayesian estimation using the Gibbs sampling technique. According to these authors, this method allows the analysis of small to large data sets, providing accurate estimates of variance components, breeding values and confidence intervals. 


\section{Results and Discussion}

For honey production, there were no differences $(p>0.05)$ between apiaries, with a variation of 8.7 to $10.8 \mathrm{~kg}$ (Table 1), presumably because they were in the same locality, in a similar landscape, with similar areas of forest and agricultural surroundings, and because the honeybees were not selected. The values were close to the mean productivity of the state of Paraná, at around $10 \mathrm{~kg}$ colony $^{-1}$ year $^{-1}$ (Silva, 2003) and below the national mean, most recently estimated by SEBRAE (2006), a maximum of $15 \mathrm{~kg}_{\text {colony }}{ }^{-1}$ year $^{-1}$.

For propolis production, apiary 2 presented the lowest production $(46.9 \pm 29.6 \mathrm{~g})$ compared to the others, with $97.5 \pm 50.4 \mathrm{~g}$ being the highest performance observed. Manrique and Soares (2002a) also found different productions between apiaries. Inoue et al. (2007) evaluated propolis production for 11 months using various methods and obtained means of $114.8 \mathrm{~g}, 120.9 \mathrm{~g}$ and $85.7 \mathrm{~g}$ using the "intelligent" collector CPI, a plastic screen and conventional scraping, respectively.

For defensive behaviour variables, the time until formation of clustering on the ball differed between apiaries 2 and 5, at 18.9 and $42.7 \mathrm{~s}$, respectively, as well in terms of the number of stings in the ball, at 22.2 and 10.8 stings, respectively. Funari et al. (2004) and Nascimento et al. (2005), evaluated the defence behaviour of bees in Botucatu (22 $52^{\prime} 20^{\prime \prime} \mathrm{S} ; 48^{\circ} 26^{\prime} 37^{\prime \prime} \mathrm{W} ; 840 \mathrm{~m}$ altitude), São

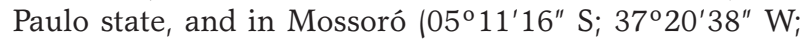
$16 \mathrm{~m}$ altitude), in Rio Grande do Norte state, Southeastern and Northeastern Brazil, respectively, obtaining a mean of 43 and 22 stings, respectively. Nascimento et al. (2005) obtained a mean time to first sting of $3.7 \mathrm{~s}$, lower than the mean obtained in this work, which ranged from 6.9 to $13.1 \mathrm{~s}$. It appears that there is variability in this characteristic between regions, counties and within the same apiary, due to genetic causes of polygenic determination (Stort, 1978; Rinderer, 1986) and environmental factors (Brandenburgo and Gonçalves, 1990), as would be expected when comparing Africanized bees (hybrid).

Regarding hygiene behaviour, three apiaries $(1,2$ and 5) were more efficient in removing dead brood than the apiary 3, and apiary 4 did not differ significantly from the others according to the $\mathrm{T}$ test. Gramacho and Gonçalves (2009a) consider honeybees to be hygienic when $80-100 \%$ of the grubs killed are removed within
$24 \mathrm{~h}$ of the test drilling. These authors observe slightly lower levels of hygiene in the Africanized colonies in Brazil (mean of $75.16 \%$ ), a variability expected in this honeybee.

\section{Correlation between characteristics in the parental generation}

The production of honey in the 30 initial colonies is not correlated with any other measured productive or behavioural characteristic (Table 2), in disagreement with Manrique and Soares (2002b), who demonstrate a positive correlation between propolis and honey production $(r=0.42)$, suggesting that the bees producing more propolis also produce more honey.

As these authors used a greater number of colonies (100) in their study, the sampling error was decreased and the phenotypic correlation between them is perhaps better represented. Another factor may that these swarms are wild, newly captured from an area of savannah and forest reserves that were previously unmanaged. In contrast, in our experiment, although the colonies were not selected, they were already managed for honey production. We found a very similar level of honey production between apiaries, which did not occur in relation to the ability of workers to exploit resources for production of propolis.

The production of propolis was not correlated with any analysed variable, although the colonies of apiary 2 had a lower production of propolis and a more pronounced defensive behaviour, as discussed previously. Variables associated with defensive behaviour did not correlate to hygienic behaviour. Studies with hygienic and unhygienic strains of European honeybees, and later with Africanized bees, revealed no correlations between hygiene and defensiveness behaviours, both in terms of polygenic inheritance and greater variability in the population (Rinderer, 1986).

The time taken until the first sting was positively correlated with the time taken for the formation of the cluster as a heat-ball ( $\mathrm{r}=0.57)$, and this was negatively correlated with the number of stings $(\mathrm{r}=-0.58)$. These results agree with those of Malaspina et al. (1989) and these correlations are understandable, since shorter times taken before attack and an increased number of stings indicate an increased aggression or defensiveness of the colony.

Table 1 - Means and standard deviations for honey production (Hon), total propolis (Pro), time to the first sting (Tab), time until formation of the clustering on the ball (Tag), number of stings (Fer) and percentage perforated brood removal (Hig) of hives from five apiaries $(n=6)$.

\begin{tabular}{|c|c|c|c|c|c|c|}
\hline Apiary & Hon & Pro & Tab & Tag & Fer & Hig \\
\hline & $\mathrm{kg}$ & g & & - & & $\%$ \\
\hline 1 & $10.27 \pm 2.51^{\mathrm{a}(1)}$ & $88.23 \pm 31.85^{\mathrm{a}}$ & $7.81 \pm 2.39^{\mathrm{ab}}$ & $28.36 \pm 11.66^{a b}$ & $16.16 \pm 3.06^{\mathrm{ab}}$ & $87 \pm 13.37^{a}$ \\
\hline 2 & $10.82 \pm 2.20^{\mathrm{a}}$ & $46.89 \pm 29.63^{b}$ & $6.91 \pm 1.50^{\mathrm{b}}$ & $18.93 \pm 8.50^{\mathrm{b}}$ & $22.16 \pm 10.61^{\mathrm{a}}$ & $83 \pm 2.73^{a}$ \\
\hline 3 & $9.71 \pm 1.70^{\mathrm{a}}$ & $81.85 \pm 42.88^{a}$ & $9.01 \pm 3.95^{\mathrm{a}}$ & $29.24 \pm 15.36^{a b}$ & $16.83 \pm 12.93^{\mathrm{ab}}$ & $64 \pm 15.37^{b}$ \\
\hline 4 & $8.65 \pm 1.35^{\mathrm{a}}$ & $68.54 \pm 42.96^{a}$ & $11.46 \pm 6.75^{\mathrm{a}}$ & $29.60 \pm 9.32^{\mathrm{ab}}$ & $12.66 \pm 4.84^{\mathrm{ab}}$ & $76 \pm 7.42^{\mathrm{ab}}$ \\
\hline 5 & $9.36 \pm 2.57^{a}$ & $97.56 \pm 50.42^{a}$ & $13.13 \pm 3.30^{\mathrm{a}}$ & $42.67 \pm 24.87^{a}$ & $10.83 \pm 2.13^{b}$ & $88 \pm 5.32^{\mathrm{a}}$ \\
\hline
\end{tabular}

${ }^{1}$ Means followed by similar letters in the column do not differ by $T$ test $(p>0.05)$. 
Some authors have found a positive correlation between the number of guard bees, age, production of the alarm pheromone, and the number of stings deposited in the ball, since the greater the number of worker guard bees, the faster is the attack (Downs and Ratnieks, 1999; Jassim et al., 2000; Sullivan et al., 2000; Breed et al., 2004; Leoncini et al., 2004). In our study, age and number of guard honeybees were not controlled.

\section{Correlation among the characteristics of the select-} ed hives: first stage

In the hives selected for propolis and honey production, propolis production did not present a correlation with productive or behavioural characteristics (Table 3), similarly to what was observed in the full set of the 30 evaluated parental colonies. In the case of propolis and honey production, the hives in each apiary showed no superiority in either simultaneously, according to the selection criteria. In apiary 1, for example, the colony which selected for higher propolis production (125.9 $\mathrm{kg}$ ) also had a high honey production $(12.8 \mathrm{~kg})$, approximately the same as the colony selected for higher honey production $(13 \mathrm{~kg})$. On the other hand, in apiary 5, the colony selected for higher honey production (12.64 kg) produced very little propolis $(1.51 \mathrm{~kg})$.

Correlations among the features of behaviour defensive observed in the analysis of all the colonies were kept and increased in the analysis in selected colonies.

Table 2 - Pearson correlation coefficients for the 30 initial hives for the variables: honey production (Hon), total propolis (Pro), defense behavior - time to the first sting (Tab), time until formation of the clustering on the ball (Tag), number of stings (Fer) and percentage perforated brood removal (Hig).

\begin{tabular}{|c|c|c|c|c|c|}
\hline Variables & Pro & Tab & Tag & Fer & $\mathrm{Hig}$ \\
\hline & g & & & & $\%$ \\
\hline Hon (kg) & -0.22 & 0.22 & 0.21 & -0.15 & 0.22 \\
\hline Pro & & 0.04 & 0.24 & 0.002 & 0.054 \\
\hline Tab & & & $0.57^{*}$ & $-0.58^{*}$ & -0.14 \\
\hline Tag & & & & $-0.52^{*}$ & -0.06 \\
\hline Fer & & & & & 0.21 \\
\hline
\end{tabular}

Table 3 - Pearson correlation coefficients and levels of significance among the variables: propolis production (Pro), defense behavior - time to the first sting (Tab), time until formation of the clustering on the ball (Tag) and number of stings (Fer), percentage perforated brood removal (Hig) and honey production (Hon), in the ten selected parental hives for honey and propolis production.

\begin{tabular}{|c|c|c|c|c|c|}
\hline & Tab & Tag & Fer & Hig & Hon \\
\hline & - & 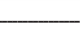 & & $\%$ & $\mathrm{~kg}$ \\
\hline Pro (g) & -0.24 & 0.06 & 0.34 & 0.03 & -0.48 \\
\hline Tab & & $0.78^{*}$ & $-0.78^{*}$ & -0.18 & -0.007 \\
\hline Tag & & & $-0.77^{*}$ & 0.15 & 0.17 \\
\hline Fer & & & & 0.06 & -0.31 \\
\hline $\mathrm{Hig}$ & & & & & $0.73^{*}$ \\
\hline
\end{tabular}

${ }^{*}$ Pearson correlation coefficients significant $(p \leq 0.05)$.
Hygiene behaviour had a rather high correlation with honey production $(\mathrm{r}=0.73)$, but this was not observed in the analysis of all 20 apiary colonies. Although the number of colonies selected was small, if this magnitude of correlation remained in the colonies daughters could suggest some genetic correlation between these traits, indicating that selection based on hygiene behaviour, which can easily be evaluated in a short period of time, might help predict honey production (Szabo, 1982; Rinderer, 1986). These authors comment that, as honey production can only be evaluated in flowering periods, the selection process for performance becomes slow.

Hygienic behaviour is genetically determined by but is not always expressed, being highly variable and determined by two, three or seven genes /Gramacho and Gonçalves, 2009b; Lapidge et al., 2002 and Rothenbühler, 1964), maternal effect (Bienefeld et al., 2007), climatic conditions such as humidity and temperature, as well as colony conditions such as population factors (Spivak and Gilliam, 1993; Gramacho et al., 1998). Malaspina et al. (1989) found no correlation between these characteristics. As the studies were undertaken in different locations, with Africanized bees, polyhybrid with high genetic variability, and that both traits are polygenic inheritance, new experiments should be conducted with larger sample size, estimating the genetic correlation between them.

\section{Correlation among characteristics in the $F_{1}$ hives: second stage}

Propolis production did not show correlation with any productive or behavioural characteristics (Table 4), in agreement with results in the whole set of colonies of the parental generation, as well as in the selected parental hives. The repetition of this tendency in their daughters reinforces the discussion, with respect to parental colonies, about the high genetic variability for propolis production, which is reflected in the capacity utilization of plant resources, as also observed by other authors (Manrique and Soares, 2002a,b).

The time until the first sting had a positive correlation with the time taken to form the cluster on the ball $(\mathrm{r}=0.87)$ and a negative correlation with the number

Table 4 - Pearson correlation coefficients and significance levels among the variables: propolis production (Pro), defense behavior time to the first sting (Tab), time until formation of the clustering on the ball (Tag), number of stings (Fer), percentage perforated brood removal (Hig) and honey production (Hon) in ten F1 hives.

\begin{tabular}{|c|c|c|c|c|c|}
\hline & Tab & Tag & Fer & $\mathrm{Hig}$ & Honey \\
\hline & & - & & $\%$ & $\mathrm{~kg}$ \\
\hline Pro (g) & 0.14 & -0.05 & -0.22 & -0.19 & 0.18 \\
\hline Tab & & $0.87^{\star}$ & $-0.76^{*}$ & -0.11 & -0.01 \\
\hline Tag & & & $-0.70^{*}$ & -0.21 & -0.04 \\
\hline Fer & & & & -0.23 & 0.38 \\
\hline Hig & & & & & -0.52 \\
\hline
\end{tabular}


of stings $(\mathrm{r}=-0.76)$, confirming the trends observed between the whole set and selected hives, in the parental generation, and highlighted the important genetic component conferred by this polygenic trait, with behavioural characteristics specific to different geographical races, as has been verified by other authors (Stort, 1978; Rinderer, 1986; Malaspina et al., 1989; Winston, 1987). Beekeepers report that, after small perturbations in the hives, more offensive attacks usually occur in Africanized bees due to rapid mobilization of the colony, resulting in a large number of stings, in contrast to more eventempered bees, which are slower to organize themselves and the intruder therefore receives less sting (Winston, 1987).

Hygiene behaviour did not present any correlation with other variables, nor to the honey production, in contrast to what was observed in the selected colonies. Honey production was damaged by the low rainfall, which may have interfered with the correlation results. According to Lohmann (2009), president of the Beekeepers Association of Paraná, the honey harvest of 2008/2009 (around $120 \mathrm{t}$ ) showed a decrease of $70 \%$ when compared to the previous year's harvest, 2007/2008 (around $400 \mathrm{t}$ ), due to excessive rain during harvesting of nectar by bees followed by a prolonged period of water shortage, so that the plants produced fewer flowers. A similar situation occurred in the rest of the state of Parana in Brazil (Alves, 2008).

\section{Heritability coefficients}

The heritability coefficients estimated were medium for honey production (0.36) and high for propolis production (0.87), time until first sting (0.86), time until formation of the bees' heat-ball (0.84), number of stings (0.71) and hygiene behaviour (0.52) (Table 5).

The heritability of honey production may have been underestimated, since there was a considerable uncontrolled environmental variation due to weather conditions during observation of the daughter colonies, as discussed. When there are major environmental variations, deviations caused by environmental components in the variations of phenotypic expression often mask the importance of the genetic component of this expression (Falconer, 1989). Honey production generally has heritabilities values ranging from low $(0.26)$ to medium (0.57), although estimated values up to 0.75 are also

Table 5 - Values for heritability $\left(\mathrm{h}^{2}\right)$, angular regression coefficient (B1) and the confidence intervals, at the $95 \%$ level.

\begin{tabular}{lcccc}
\hline Variable & $\mathrm{h}^{2}$ & $\mathrm{~B}_{1}$ & \multicolumn{2}{c}{$\begin{array}{c}\text { Confidence interval } \\
\text { (95\%) }\end{array}$} \\
\hline Honey production & 0.36 & 0.18 & 0.01 & 0.47 \\
Propolis production & 0.87 & 0.43 & 0.28 & 0.49 \\
Time to first sting & 0.86 & 0.43 & 0.28 & 0.49 \\
Number of stings & 0.71 & 0.35 & 0.10 & 0.49 \\
Time for clustering & 0.84 & 0.42 & 0.25 & 0.40 \\
Hy Removal perforated brood & 0.52 & 0.26 & 0.14 & 0.48 \\
\hline
\end{tabular}

reported (Rinderer, 1986; Bienefeld et al., 2007). CostaMaia et al. (2011) found values of between 0.40 to 0.47 , using queens' morphometric characteristics as a selection criterion.

Accurate estimation of the genetic value of individuals, and hence the heritability, depends on the genetic differences in the population, the environment, the type of analysis, the method of estimating the variance and covariance components, and the effects included in the statistical model for the evaluation of animals (Bienefeld et al., 2007). These authors estimated genetic parameters through the minimum squares method; however, in our work we used Bayesian inference, as have other authors (Toledo et al., 2010; Costa-Maia et al., 2011; Faquinello et al., 2011), in researching other features of Africanized honeybees. This method allows analysis of small to large data sets, providing accurate estimates of variance components, breeding values and confidence intervals (Van Tassel and Van Vleck, 1995).

The coefficient of heritability determined for propolis production in our experiment was 0.87 . Such a coefficient is considered high in comparison to the classification of Rinderer (1986) and Falconer (1989); therefore the variations observed between the hives for this characteristic could be attributed more to the genetic variations between them than to environmental effects and, hence, significant increases in hive propolis production could be obtained through selection by performance.

Considering defence behaviour, the estimated heritability values were 0.71 for number of stings, 0.86 for time until the first sting, and 0.84 for time until formation of the heat-ball. Brandenburgo (1993) obtained low heritability values, from 0.02 to 0.05 , for defence behaviour. Bienefeld and Pirchner (1990) estimated genetic parameters through the minimum squares method and determined a value of 0.41 for heritability for the same defence behaviour characteristics.

Given the variable heritability values obtained in different studies, it is important to note that heritability is a property not only of a specific character, but varies from population to population and in accordance with variations in the environmental component, and heritability value estimates made for one population may be different for that same population in another environment, or for a different population (Rinderer, 1986). The high heritability estimates in this study confirmed the importance of the genetic component of the observed variations for these characteristics, as discussed by others authors (Melo et al., 1997; Guzman-Novoa et al., 2005) and as cited in the correlations between the characteristics associated with this behaviour, both in the parental and $\mathrm{F}_{1}$ generations.

The heritability coefficient obtained for the hygiene behaviour was 0.52 , considered "medium to high" when compared to the coefficients of most of the other biological characteristics (Rinderer, 1986; Falconer, 1989). The values for the removal of pupae from perforated cells were very similar in parental selected and $\mathrm{F}_{1}$ generations 
(Table 6). This heritability value was lower than that found by Harbo and Harris (1999), which was 0.65 for removal of the perforated brood $24 \mathrm{~h}$ after death. Those authors suggested that a heritability value higher than 0.25 is indicative of potential selection. Boecking et al. (2000) found a heritability estimate of 0.36 for removal of a perforated brood from 13 to $15 \mathrm{~h}$ after perforation. On the other hand, Milne (1985) estimates relatively low values: 0.14 for uncapping and 0.02 for removal of the dead capped brood, similarly to Costa-Maia et al. (2011), who estimate heritability values of $0.28,0.15,0.24$, for removal of dead brood at 24,48 and 72 hours after perforation, respectively.

\section{Comparison of characteristics between generations}

There was a reduction in honey production from the parental to $F_{1}$ generation, in the colonies selected both for honey and propolis production (Table 6). As already discussed, there was a severe reduction in honey production across the state of Paraná due to unfavourable conditions for the $\mathrm{F}_{1}$ generation exerting a strong influence on this trait, with heritability 0.36 in this research, and so more influenced by environmental components than genetic factors. Honey production heritability is generally considered as low-moderate (Rinderer, 1986; Bienefeld et al., 2007; Costa-Maia et al., 2011). Thus, the phenotypic value is somewhat related to the genetic value of the colonies but, according to Rinderer (1986), selection based on this characteristic can yield a good genetic gain, especially if they are used to aid selection, as representing data from relatives.

For honey production, the phenotypic homogeneity of the experimental colonies in the parental generation was reflected in the small selection differential (that is, the difference between the means of the entire 30 hive population and the 10 selected experimental hives), both of colonies selected for honey production (1.79 kg) and those selected for propolis production (0.19 kg). Therefore, the genetic gain was low not only because of the low heritability of traits (influenced by the large environmental variation), but also by low selection differentials observed in the parental generation, as a characteristic genetic gain is equal to the product of their differential selection in the parental generation for its heritability (Falconer, 1989).

Propolis production was less influenced by large differential in rainfall in the $\mathrm{F}_{1}$ generation (reduction of $15.55 \%$ ) than was honey production (reduction of $62.57 \%)$. In this case, the genetic component has great importance for the observed phenotypic variability, as evidenced by the high estimate of heritability at 0.87 . Selection for honey production can be effective, especially if information from allied colonies is used, and will be slower if only using information about the parental colony from which queens are being selected. Our data suggested that propolis production can be improved by selecting the queens, based on information from the colony itself, for training of future generations. It can also be incorporated into breeding programmes, perhaps with the formation of productive strains, although this is more difficult with Africanized bees (polyhybrids), due to their high genetic heterogeneity.

Regarding behavioural variables, the colonies that were more defensive and more hygienic in the parental generation also showed the same behaviour in the $\mathrm{F}_{1}$ generation, as confirmed by the high heritability estimates. Thus, the values for these characteristics relating to the colonies' mothers can be effectively used to predict equivalent values in the colonies' daughters. However, given the significant correlations with production traits, this would not be effective as an indirect selection criterion for the production of either honey or propolis.

\section{Acknowledgements}

To the State University of West Paraná (UNIOESTE), National Council for Scientific and Technology (CNPq) and Department of Science, Technology and Higher Education of the Paraná State (SETI) to support this project and to grant fellowship.

Table 6 - Means and standard deviation for honey and propolis production, defense behavior - time to first sting, time until formation of the clustering on the ball, number of stings; percentage perforated brood removal of the total and selected colonies (by honey and propolis production) in parental and F1 generations.

\begin{tabular}{lccc}
\hline \multirow{2}{*}{ Variable/selection criteria } & \multicolumn{2}{c}{ Parental } & \multicolumn{2}{c}{$F_{1}$} \\
\cline { 2 - 3 } Honey production (kg) & Total & $10.74 \pm 2.13^{*}(10)$ & $4.02 \pm 4.29(10)$ \\
- by honey production (kg) & $9.75 \pm 2.10(30)$ & $11.54 \pm 1.93^{*}(5)$ & $3.37 \pm 4.61(10)$ \\
- by total propolis production (kg) & & $9.94 \pm 2.21^{*}(5)$ & $4.67 \pm 4.36(10)$ \\
Total propolis production (g) & $76.61 \pm 41.48(30)$ & $74.52 \pm 54.29(10)$ & $63.23 \pm 47.75(10)$ \\
- by total propolis production (g) & & $122.14 \pm 25.04(5)$ & $107.16 \pm 12.06(10)$ \\
- by honey production (g) & & $26.91 \pm 17.5(5)$ & $19.30 \pm 12.67(10)$ \\
Time to the first sting (s) & $9.67 \pm 4.40(30)$ & $10.74 \pm 5.74(10)$ & $7.54 \pm 3.83(10)$ \\
Time for clustering (s) & $29.76 \pm 16.04(30)$ & $27.45 \pm 3.72(10)$ & $23.72 \pm 10.62(10)$ \\
Number of stings & $15.73 \pm 8.39(30)$ & $17.70 \pm 10.13(10)$ & $16.00 \pm 7.60(10)$ \\
Removal brood perforated (\%) & $79.83 \pm 13.05(30)$ & $83.20 \pm 12.52(10)$ & $83.70 \pm 9.94(10)$ \\
\hline
\end{tabular}

* means of selected colonies differ from means of F1 colonies (T test, $p \leq 0.05$ ). The number in parentheses represents sample size. 


\section{References}

Al-Tikrity, W.S.; Hillmann, R.C.; Benton, A.W. 1971. A new instrument for brood measurement in a honey-bee colony. American Bee Journal 111: 20-21.

Alves, W. 2008. Clima instável diminui produção de mel no Paraná = Unstable climate decreases honey production in Paraná. Available at:http://www.pron.com.br/editoria/cidades/news/115146 [Accessed Jul. 17, 2009] (in Portuguese).

Bienefeld, K.; Pirchner, F. 1990. Heritabilities for several colony traits in the honeybee (Apis mellifera carnica). Apidologie 21: 175-183.

Bienefeld, K.; Ehrardt, K.; Reinhardt, F. 2007. Genetic evaluation in the honey bee, considering queen and worker effects: a BLUP; Animal model approach. Apidologie 38: 77-85.

Brandenburgo, M.A.M. 1993. A safe device for extration venom from honeybees (A mellifera). Bee World, 73: 128-130.

Brandenburgo, M.A.M.; Gonçalves, L.S. 1990. A study on the changes in defense behavior of Africanized honeybees during a period of one year. Ciência e Cultura 42: 759-771. (in Portuguese, with abstract in English).

Breed, M.D.; Guzman-Novoa, E.; Hunt, G.J. 2004. Defensive behavior of honey bees: organization, genetics, and comparison with other bees. Annual Review Entomology 49: 271-298.

Clarke, K.E; Rinderer, T.E.; Franck, P.; Quezada-Euán, J.G.; Oldroyd, B.P. 2002. The Africanization of honeybees (Apis mellifera L.) of the Yucatan: a study of a massive hybridization event across time. Evolution 56: 1462-1474.

Costa-Maia, F.M.; Toledo, V.A.A.; Martins, E.N.; Lourenço, D.A.L.; Sereia, M.J.; Oliveira, C.A.L.; Faquinello, P.; Halak, A.L. 2011. Estimates of covariance components for hygienic behavior in Africanized honeybees (Apis mellifera). Revista Brasileira de Zootecnia 40: 1909-1916.

De Jong, D. 1996. Africanized honey bees in Brazil, forty years of adaptation and success. Bee World 77: 67-70.

Doolittle, G.M. 1899. Doolittle's queen rearing methods. American Bee Journal 39: 435-436.

Downs, S.G.; Ratnieks, F.L.W. 1999. Recognition of conspecifics by honeybee guards uses nonheritable cues acquired in the adult stage. Animal Behavior 58: 643-648.

Falconer, D.S. 1989. Introduction to quantitative genetics. John Wiley \& sons, New York, N.Y., U.S.A..

Faquinello, P.; Toledo, V.A.A.; Martins, E.N.; Oliveira, C.A.L.; Sereia, M.J.; Costa-Maia, F.M.; Rúvolo-Takasusuki, M.C.C. 2011. Parameters for royal jelly production in Africanized honeybees. Sociobiology 57: 495-509.

Fletcher, D.J. 1978. The African bee, Apis mellifera adansoni. Annual Review of Entomology 23: 151-171.

Funari, S.R.C.; Orsi, R.O.; Rocha, H.C.; Sforcin, J.M. 2004. Influence of smoke and lemon grass (Cymbopogon citratus) in the defensive behavior of Africanized honey bees and their hybrid European (Apis mellifera L.). Boletim da Indústria Animal 61: 121-125. (in Portuguese, with abstract in English).

Garcia, R.C.; Nogueira-Couto, R.H.N. 2003. Colonies development of Africanized and italian Apis mellifera and descendents of their crosses. Varia Scientia 03: 111-121. (in Portuguese, with abstract in English).
Gramacho, K.P.; Gonçalves, L.S. 2009a. Sequential hygienic behavior in Carniolan honey bees (Apis mellifera carnica). Genetics and Molecular Research 8: 655-663.

Gramacho, K.P.; Gonçalves, L.S. 2009b. Comparative study of the hygienic behavior of Carniolan and Africanized honey bees directed towards grouped versus isolated dead brood cells. Genetics and Molecular Research 8: 744-750.

Gramacho, K.P.; Gonçalves, L.S.; Rosenkranz, P. 1998. Study of the temperature of brood killed by the pin-killing method in worker bees of Apis mellifera carnica. Apiacta 33: 33-41.

Guzman-Novoa, E.; Hunt, G.J.; Page, R.E.; Uribe-Rubio Jr., J.L.; Prieto-Merlos, D.; Becerra-Guzman, F. 2005. Paternal effects on the defensive behavior of honeybees. Journal of Heredity 96: $376-380$

Hepburn, H.R.; Radloff, S.E. 1998. Honeybees of Africa. Spinger, Berlin, Germany.

Inoue, H.T.; Sousa, E.A.; Orsi, R.O.; Funari, S.R.C.; Barreto, L.M.R.C.; Dib, A.P.S. 2007. Propolis production by differents methods. Asociación Latinoamericana de Producción Animal 15: 65-69.

Instituto Agronômico do Paraná [IAPAR]. 2008. Cartas climáticas do Paraná. = Letters climate of Paraná. Available at: http:// www.1200.2001.27.14/sete/sma/cartas_climaticas/classificação_ climatica.html [Accessed Dec. 15, 2008] (in Portuguese).

Instituto Brasileiro de Geografia e Estatística [IBGE]. 2009. Pesquisa da Pecuária Nacional. = Research of national livestock. Available at: http://www.sidra.ibge.gov.br/bda/ tabela/lista.asp? $\mathrm{c}=74 \& \mathrm{z}=\mathrm{p} \& \mathrm{o}=23$ [Accessed Sep. 30, 2011] (in Portuguese)

Jassim, O.; Huang, Z.Y.; Robinson, G.E. 2000. Juvenile hormone profiles of worker honey bees, Apis mellifera, during normal and accelerated behavioural development. Journal of Insect Physiology 46: 243-249.

Kaplan, J. K. 2007. Africanized honey bees in the news again. Agricultural Research, 54: 4-7.

Kerr, W.E. 1967. The history of the introduction of Africanized honey bees to Brazil. South African Bee Journal 39: 3-5.

Leoncini, I.; Le-Conte, Y.; Costagliola, G.; Plettner, E.; Toth, A.L.; Wang, M.W.; Huang, Z.; Becard, J.M.; Crauser, D.; Slessor, K.N.; Robinson, G.E. 2004. Regulation of behavioral maturation by a primer pheromone produced by adult worker honey bees. Proceedings of the National Academy of Sciences 101: 17559-17564.

Lobo, J.A.; Krieger, H. 1992. Maximum-likelihood estimates of gene frequencies and racial admixture in Apis mellifera L. (Africanized honeybees). Heredity 68: 441-448.

Lohmann, L.D. 2009. Safra de mel na região registra quebra de até $70 \%$. = Honey crop in the region break records up to $70 \%$. Available at: http://www.opresente.com.br/geral/safra-de-melna-regiao-registra-quebra-de-ate-70-569/ [Accessed Nov. 27, 2011] (in Portuguese).

Malaspina, O.; Stort, A.C.G..; Correa-Bueno, O. 1989. Analysis of morphological and behavioral characters in Bees Africanized, Caucasian and descendants of their crossings. Revista Brasileira de Zoologia 6: 63-73 (in Portuguese, with abstract in English).

Manrique, A.J.; Soares, A.E.E. 2002a. Seleção de abelhas africanizadas para produção de própolis. = Selection of Africanized bees to propolis production. Zootecnia Tropical 20: 235-246 (in Portuguese). 
Manrique, A.J.; Soares, A.E.E. 2002b. Initiation of a selection program of Africanized bees for improved production of propolis and its effect on honey production. Revista Interciência 27: 312-316 (in Portuguese, with abstract in English).

Melo, A.; Malaspina, O.; Diniz-Filho, J.A.F. 1997 Heritability of sting characters in Africanized honeybees. Journal of Venomous Animals and Toxins 3: 274-279.

Nogueira-Couto, R.H.; Couto, L.A. 2006. Beekeeping: management and products. Funep, Jaboticabal, SP, Brazil (in Portuguese, with abstract in English).

R Development Core Team. 2011. R: A language and environment for statistical computing. $\mathrm{R}$ Foundation for Statistical Computing, Vienna, Austria. ISBN 3-900051-07-0, Available at: URL http://www.R-project.org/ [Accessed Jul. 03, 2011]

Rinderer, T.E., 1986. Bee Genetics and Breeding. Academic Press, Orlando, FL, USA.

Rinderer, T. E.; Oldroyd, B. P.; Sheppard, W. S. 1993. Africanized bee in the United States. Scientific American, 269: 52-58.

Serviço Brasileiro de Apoio às Micro e Pequenas Empresas [SEBRAE]. 2006. Mudanças na Apicultura Brasileira. = Challenges of the Brazilian Apiculture. SEBRAE, Brasília, DF, Brazil (in Portuguese).

Sheppard, W.S.; Soares, A.E.E.; De Jong, D.; Shimanuki, H. 1991a. Hybrid status of honey bee populations near the historic origin of Africanization in Brazil. Apidologie 22: 643-652.

Sheppard, W.S.; Rinderer, T.E.; Mazzoli, J.A.; Stelzer, J.A.; Shimanuki, H. 1991b. Gene flow between African- and European- derived honey bee populations in Argentina. Nature 349: $782-784$.
Silva, R.C.P.A. 2003. Apicultura - Mundo - Brasil = Beekeeping - World, Brazil - Paraná. SEAB, Curitiba, PR, Brazil. (in Portuguese).

Snedecor, G.W.; Cochran, W.G. 1989. Statistical methods. University Press, Ames, Iowa, USA.

Spivak, M.; Gilliam, M. 1993. Facultative expression of hygienic behaviour of honey bees in relation to disease resistance. Journal of Apicultural Research 32: 147-157.

Stort, A.C. 1978. Genetic study of aggressiveness of two subspecies of $A$. mellifera in Brazil. VII. Correlation of the various aggressiveness characters among each other and with the gens for abdominal color. Ciência e Cultura 30: 491-496.

Szabo, T.I. 1982. Phenotypic correlations between colony traits in the honey bee. American Bee Journal 122: 711-716.

Toledo, V.A.A.; Neves, C.A.; Alves, E.M.; Oliveira, J.R.; RuvoloTakasusuki, M.C.C.; Faquinello, P. 2010. Production of royal jelly in colonies of Africanized bees considering different protein supplements and the influence of environmental factors. Acta Scientiarum. Animal Sciences 32: 93-100.

Van Tassel, C.P.; Van Vleck, L.D. 1995. A manual for use of MTGSAM: a set of Fortran programs to apply Gibbs sampling to animal models for variance components estimation. USDA/ ARS, Washington, DC, USA.

Winston, M.L. 1987. The Biology of the Honey Bee. Harvard University Press, London, England. 